\title{
Pengaruh Diskon 9.9 Super Shoping Day Shopee terhadap Minat Beli Pengguna Aplikasi Shopee
}

\author{
Aditya Putra Pratama, Moehammad Gafar Yoedtadi \\ aditya.915170070@stu.untar.ac.id,gafary@fikom.untar.ac.id
}

Fakultas Ilmu Komunikasi Universitas Tarumanagara

\begin{abstract}
This study aims to determine the effect of the Shopee discount program on the purchase interest of Shopee application users. The study population was the community in the neighborhood RT03 RW024 Perumahan Villa Gading Harapan, Bekasi. The theory used is the marketing mix theory, discount theory, and purchase interest. In this study, the authors of a questionnaire to 48 Shopee applications who live in the residential area of Villa Gading Harapan, Bekasi. The questionnaire was distributed via a Google form. Data analysis techniques use resistance test, regression analysis test, and hypothesis testing. Sampling using purposive sampling technique. From the results of questionnaire data processing assisted by the SPSS program, it was found that the program had (moderate) effect on the purchase interest of Shopee user applications. And each discount variable has a percentage of 50\% which indicates that there is an effect of the discount program from Shopee.
\end{abstract}

Keywords: buying interest, discount, marketing mix

\begin{abstract}
Abstrak
Penelitian ini bertujuan untuk mengentahui pengaruh program diskon Shopee terhadap minat beli pengguna aplikasi Shopee. Populasi penelitian ini adalah masyarakat di lingkungan RT03 RW024 Perumahan Villa Gading Harapan, Bekasi. Teori yang digunakan adalah teori bauran pemasaran, teori diskon, dan minat beli. Pada penelitian ini penulis menyebarkan kuesioner kepada 48 orang pengguna aplikasi Shopee yang berdomisili di lingkungan Perumahan Villa Gading Harapan, Bekasi. Kuesioner disebarkan melalui Google form. Teknik analisa data mengguanakan uji korelasi, uji analisis regresi,dan uji hipotesis. Penarikan sampel menggunakan teknik purposive sampling. Dari hasil pengolahan data kuesioner yang dibantu dengan program SPSS didapatkan hasil bahwa ternyata program diskon berpengaruh (sedang) terhadap minat beli pengguna aplikasi Shopee. Dan di setiap variabel diskon memiliki presentase sebesar $50 \%$ yang menunjukkan bahwa adanya pengaruh program diskon dari Shopee.
\end{abstract}

Kata Kunci: bauran pemasaran, diskon, minat beli

\section{Pendahuluan}

Berbelanja merupakan kegiatan yang wajar dilakukan oleh setiap orang. Kegiatan berbelanja juga dipengaruhi oleh kemajuan teknologi. Umumnya orang berbelanja datang langsung ke toko atau pusat perbelanjaan. Namun sekarang berbelanja dapat dilakukan hanya dari rumah menggunakan telepon pintar. Barang yang dibeli diantar oleh kurir hingga ke pintu rumah. Cara ini biasa disebut perdagangan eletronik atau e-commerce. E-commerce menawarkan kemudahan dalam transaksi belanja. Kemudahan untuk produsen karena bisa menjual produk atau jasanya secara daring tanpa harus memiliki toko sehingga produsen atau penjual dapat 
memasarkan produknya kapanpun dan dimanapun kepada konsumennya. Dari segi pemasarannya, produsen tidak perlu lagi mengeluarkan biaya untuk promosi dikarenakan adanya jaringan internet, produsen mampu memasarkan produk dan jasanya secara luas kepada masyarakat (Shintya,2019).

Shopee yang diluncurkan pada 2015 silam, merupakan platform e-commerce terkemuka di Asia Tenggara dan Taiwan. Untuk menuai banyak konsumen, biasanya toko daring, memberikan diskon yang beragam. Mulai dari diskon pada produk dengan merek tertentu seperti yang dilakukan oleh toko konvensional atau mall. Salah satunya adalah diskon per periode atau pada tanggal di bulan tertentu seperti yang dilakukan oleh toko daring Shoppe. Shopee mengadakan diskon setiap sebulan sekali di tanggal tertentu. Salah satunya adalah diskon pada tanggal 9 September 2020 yang lalu, yaitu diskon 9.9 Super Shopping Day. Menurut Lexchin \& Mintzes (Amir,2013) promosi dalam bentuk potongan harga (diskon) secara konsisten akan mengakibatkan peningkatan minat beli pada konsumen.

Menururt Tjiptono diskon yaitu potongan harga yang diberikan produsen kepada konsumen sebagai bentuk penghargaan atas pembelian tertentu, dari konsumen yang menyenangkan bagi penjual (Dewi,2018). Sementara minat beli menurut Ferdinand terkait perencanaan untuk membeli produk serta jumlah unit yang dibutuhkan konsumen pada kurun waktu tertentu (Silaningsih, 2018: 145). Mujiono mengatakan minat beli merupakan aktivitas psikis yang timbul dikarenakan adanya perasaan (afeksi) dan pikiran (kognitif) kepada suatu barang atau jasa yang diinginkan (Susantio, 2019: 240). Berdasarkan latar belakang diatas, rumusan masalah pada penelitian ini adalah sebagai berikut: adakah pengaruh diskon 9.9 super shopping day Shopee terhadap minat beli masyarakat di lingkungan RT03 / RW024 Komplek Villa Gading Harapan Bekasi?.

Sedangkan tujuan penelitian ini untuk mengetahui pengaruh diskon 9.9 super shopping day terhadap minat beli pengguna aplikasi Shopee, dan seberapa besar pengaruh diskon tersebut terhadap minat beli masyarakat di lingkungan RT03 / RW024 Komplek Villa Gading Harapan.

\section{Metode Penelitian}

Penulis menggunakan metode kuantitatif dalam penelitian ini untuk menganalisa data metode penelitian kuantitatif, umumnya masalah yang diteliti mempunyai cakupan yang lebih luas serta variasi yang lebih kompleks dibandingkan dengan penelitian kualitatif. Metode yang dipakai dalam penelitian ini yaitu metode survei. Metode survei adalah metode penelitian dengan memakai kuesioner sebagai instrumen untuk mengumpulkan data (Siyoto, 2015). Teknik yang digunakan untuk penarikan sampel dari penelitian ini adalah teknik purposive sampling Menurut Sugiyono, dalam Dwitasari (2019) purposive sampling adalah teknik menentukan sampel dengan pertimbangan tertentu, Populasi dan sampel pada penelitian ini merupakan masyarakat yang berada di lingkungan RT 03 RW 024 Perumahan Villa Gading Harapan, Bekasi. Sampel dalam penelitian ini berjumlah sebanyak 48 orang. Untuk mengumpulan data pada penelitian ini digunakan google form sebagai media untuk menyebarkan kuesioner. Penelitian ini menggunakan uji korelasi, uji analisis regresi, uji hipotesis, ujivaliditas, uji reliabilitasdan uji normalitas untuk mengolah data yang diperoleh. 


\section{Hasil Temuan dan Diskusi}

Kuesioner pada penelitian ini disebarkan kepada sebanyak 48 responden dan didapatkan data berupa responden berjenis kelamin laki - laki sebanyak 34 responden $(70,8 \%)$ dan responden berjenis kelamin perempuan sebanyak 14 responden $(29,2 \%)$. Lalu usia responden dalam penelitian ini beragam mulai dari 33 tahun sampai 53 tahun. Setelah melakukan uji validitas menggunakan program SPSS maka didapatkan hasil seperti dibawah ini:

Tabel 1. Uji Validitas

\begin{tabular}{|c|c|c|c|}
\hline Variabel & Butir Indikator & $\begin{array}{c}\text { Corrected } \\
\text { Item Total } \\
\text { Correlation }\end{array}$ & Keterangan \\
\hline \multirow{4}{*}{$\begin{array}{l}\text { Program } \\
\text { Diskon }\end{array}$} & $\begin{array}{l}\text { Membeli Barang Apabila Ada Diskon } \\
\text { Pada produk Tertentu, Meskipun Dengan } \\
\text { Syarat Harus Membeli Dengan Jumlah } \\
\text { Tertentu. }\end{array}$ & 0,598 & Valid \\
\hline & $\begin{array}{l}\text { Lebih Suka Membeli Barang Dengan } \\
\text { Cara Cash Dikarenakan Adanya Diskon } \\
\text { Bila Membeli Dengan Cara Cash. }\end{array}$ & 0,609 & Valid \\
\hline & $\begin{array}{l}\text { Tetap membeli produk diShopee meski } \\
\text { sedang tidak ada diskon bulanan. }\end{array}$ & 0,582 & Valid \\
\hline & $\begin{array}{l}\text { Anda Berbelanja diShopee Karena } \\
\text { Adanya Diskon Diluar Hari - Hari Besar } \\
\text { Seperti Hari Raya Lebaran dan Hari Raya } \\
\text { Natal }\end{array}$ & 0,521 & Valid \\
\hline \multirow{5}{*}{$\begin{array}{c}\text { Minat } \\
\text { Beli }\end{array}$} & $\begin{array}{l}\text { Membeli Barang Apabila Ada Diskon } \\
\text { Pada produk Tertentu, Meskipun Dengan } \\
\text { Syarat Harus Membeli Dengan Jumlah } \\
\text { Tertentu. }\end{array}$ & 0,627 & Valid \\
\hline & $\begin{array}{l}\text { Lebih Suka Membeli Barang Dengan } \\
\text { Cara Cash Dikarenakan Adanya Diskon } \\
\text { Bila Membeli Dengan Cara Cash. }\end{array}$ & 0,629 & Valid \\
\hline & $\begin{array}{l}\text { Anda merekomendasikan barang yang } \\
\text { anda beli melalui Shopee kepada sesama } \\
\text { masyarakat di lingkungan RT03 RW } 024 \text {. }\end{array}$ & 0,632 & Valid \\
\hline & $\begin{array}{l}\text { Seberapa sering anda merekomendasikan } \\
\text { barang yang anda beli melalui Shopee } \\
\text { kepada sesama masyarakat di lingkungan } \\
\text { RT03 RW } 024 \text {. }\end{array}$ & 0,531 & Valid \\
\hline & $\begin{array}{l}\text { Anda mencari informasi tentang produk } \\
\text { yang anda minati, melalui Shopee? }\end{array}$ & 0,710 & Valid \\
\hline
\end{tabular}


Mencari Informasi Pendukung Yang

Bersifat Positif Melalui Shopee Tentang

0,738

Valid

Produk Yang Sudah Lama Anda Pakai.

Memilih barang dengan produk lain, dengan alasan mengalami kerusakan pada produk yang digunakan saat ini.

$0,706 \quad$ Valid

Anda memiliki minat dan keutamaan

terhadap merek tertentu yang anda beli di

0,617

Valid

Shopee?

Sumber: Hasil Pengolahan Data Peneliti

Tabel 1 menunjukkan bahwa setiap butir indikator pertanyaan dari seluruh variabel dinyatakan valid. Karena,memiliki angka korelasi diatas 0,2.

Tabel 2 Uji Reliabilitas

\begin{tabular}{ccc}
\hline Variabel & Cronbach's Alpha & Keterangan \\
\hline Program Diskon & 0,774 & Reliable \\
\hline Minat Beli & 0,878 & Reliable \\
\hline
\end{tabular}

Sumber: Hasil Pengolahan Data Peneliti

Tabel 2 menunjukkan bahwa diperoleh nilai Cronbach's Alpha lebih dari 0,6. Yang artinya variabel $\mathrm{X}$ dan $\mathrm{Y}$ pada penelitian ini dinyatakan reliable.

Gambar 1. Uji Normalitas

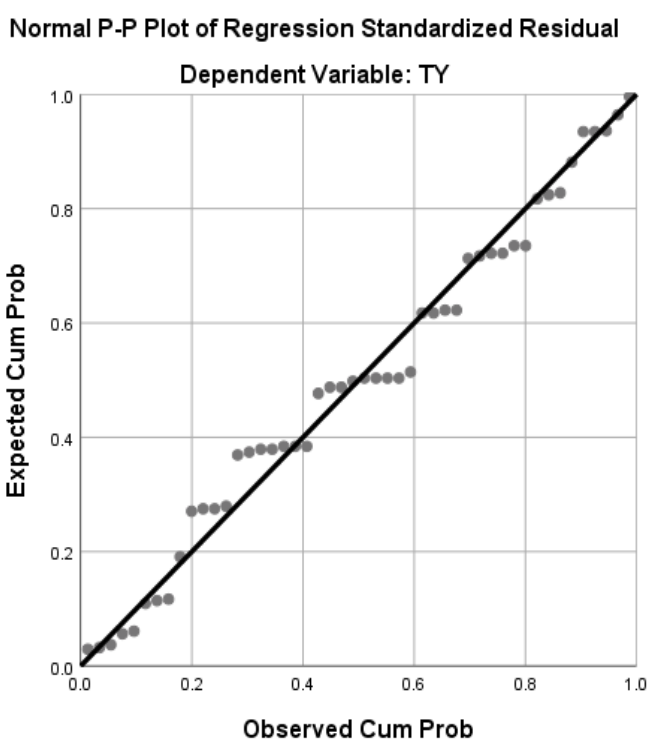

Sumber: Hasil Pengolahan Data Peneliti

Berdasarkan grafik pada gambar, terlihat data menyebar disekitar garis diagonal dan mengikuti arah garis diagonal Grafik ini menandakan bahwa data yang diolah berdistribusi normal, karena semakin dekat suatu data dengan garis lurus, artinya pendistribusiannya semakin normal. 
Tabel 3. Uji Korelasi

\begin{tabular}{lcccc}
\hline Model & $\boldsymbol{R}$ & $\boldsymbol{R}$ Square & $\begin{array}{c}\text { Adjusted } \boldsymbol{R} \\
\text { Square }\end{array}$ & $\begin{array}{c}\text { Std. Error of } \\
\text { the Estimate }\end{array}$ \\
\hline $\mathbf{1}$ & $.518^{\mathrm{a}}$ & .269 & .253 & 3.298 \\
\hline
\end{tabular}

Sumber: Hasil Pengolahan Data Peneliti

Bila dilihat pada tabel di atas, diketahui bahwa nilai koefisien korelasi $\mathrm{R}$ sebesar 0,518 yang berada di antara interval $0,40-0,599$ artinya program diskon mempunyai hubungan yang sedang terhadap minat beli.

Tabel 4 Analisis Regresi

\begin{tabular}{|c|c|c|c|c|c|c|}
\hline \multicolumn{2}{|c|}{ Model } & \multicolumn{2}{|c|}{$\begin{array}{c}\text { Unstandardized } \\
\text { Coefficients }\end{array}$} & \multirow[t]{2}{*}{$\begin{array}{l}\text { Standardized } \\
\text { Coefficients }\end{array}$} & \multirow[t]{2}{*}{$\mathbf{t}$} & \multirow[t]{2}{*}{ Sig } \\
\hline 1 & (Constant) & B & $\begin{array}{l}\text { Std. } \\
\text { Error }\end{array}$ & & & \\
\hline & & 17,765 & 3,953 & & 4,494 & 0,000 \\
\hline & & 0,956 & 0,233 & 0,518 & 4,111 & 0,000 \\
\hline
\end{tabular}

Sumber: Hasil Pengolahan Data Peneliti

Nilai Y (Minat Beli) akan tetap sebesar 17,765 konstanta jika nilai X (Program Diskon) tidak ada perubahan, baik peningkatan maupun penurunan. Jika nilai $\mathrm{X}$ (Program Diskon) mengalami peningkatan nilai sebesar 1 satuan, maka nilai Y (Minat Beli) akan meningkat sebesar 0,956 menjadi 18,721.

Tabel 5 Uji Hipotesis

\begin{tabular}{llccccc}
\hline Model & & $\begin{array}{c}\text { Sum of } \\
\text { Squares }\end{array}$ & Df & $\begin{array}{c}\text { Mean } \\
\text { Square }\end{array}$ & F & Sig. \\
\hline $\mathbf{1}$ & Regression & 183.891 & 1 & 183.891 & 16.898 & $.000^{\mathrm{b}}$ \\
\cline { 2 - 8 } & Residual & 500.588 & 46 & 10.882 & & \\
\cline { 2 - 5 } & Total & 684.479 & 47 & & & \\
\hline
\end{tabular}

Sumber: Hasil Pengolahan Data Peneliti

Tabel 5 menunjukkan bahwa dengan hasil Sig $=0,000<0,05$ maka $\mathrm{H}_{0}$ ditolak dan $\mathrm{H}_{1}$ diterima $\mathrm{Hal}$ ini menujukan bahwa terdapat pengaruh diskon terhadap minat beli.

\section{Simpulan}

Berdasarkan penelitian yang telah dilakukan, dapat ditarik kesimpulan bahwa terdapat Pengaruh Diskon 9.9 Super Shoping Day Shopee Terhadap Minat Beli Pengguna Aplikasi Shopee (studi pada masyarakat di lingkungan RT 03 RW 024 di Villa Gading Harapan, Bekasi). Dari hasil uji korelasi didapatkan, Berdasarkan hasil penelitian ini pada variabel $X$ (program diskon) masing - masing indikatornya memiliki pengaruh mininal 50\% terhadap variabel Y ( minat beli). Juga diperkuat dengan hasil hipotesis dengan hasil Sig $=0,000$ kurang dari 0,05 yang membuat $\mathrm{H}_{1}$ diterima. Setelah dilakukannya uji korelasi didapat $\mathrm{R}$ sebesar 0,518 yang berada di antara interval 0,40- 0,599 yang artinya terdapat pengaruh antara diskon Shopee 
Aditya Putra Pratama, Moehammad Gafar Yoedtadi: Pengaruh Diskon 9.9 Super Shoping Day Shopee terhadap Minat Beli Pengguna Aplikasi Shopee

terdapap minat beli pengguna aplikasinya dan memiliki tingkat pengaruh / hubungan sedang.

\section{Ucapan Terima Kasih}

Puji syukur atas kehadiran Tuhan Yang Maha Esa karena atas berkat dan rahmat-Nya penulis dapat menyelesaikan penelitian ini. Tidak lupa ucapan terimakasih juga penulis berikan kepada keluarga tercinta, Fakultas Ilmu Komunikasi Universitas Tarumanagara, teman - teman dekat penulis serta semua orang yang terlibat dalam penelitian ini. terimakasih telah mendukung dan menyemanganti penulis selama proses penulisan skripsi ini.

\section{Daftar Pustaka}

Amir, Faesol (2013) Efektifitas disokon dan hadiah sebagai sarana romosi penjualan untuk menarik niat beli konsumen. Jurnal Managemen Bisnis. 3 (1). 44-53

Dewi, Kusumawati , (2018) Pengaruh diskon terhadap keputusan pembelian dan kepuasan pelanggan bisnis online (survei pada mahasiswa fakultas ilmu administrasi universitas brawijaya angkatan 2013/2014 konsumen traveloka). Jurnal Administrasi Bisnis. 56 (1). 155-163

Dwitasari, (2019) Pengaruh kemudahan penggunaan dan kenikmatan berbelanja serta kepercayaan konsumen terhadap minat beli konsumen di aplikasi jual beli online shopee pada fakultas ekonomi dan bisnis Universitas Jember. Digital Repository Universitas Jember. 1-87

Shintya, (2019) Seputar e-Commerce, Manfaat Hingga Jenisnya. 6 September 2019 $<\underline{\text { https://inet.detik.com/business/d-4696146/seputar-e-commerce-manfaat- }}$ hingga-jenisnya $>$, diunduh pada 25 September 2020

Silaningsih, Utami, (2018). Pengaruh marketing mix terhadap minat beli konsumen pada usaha mikro kecil dan menengah (umkm) prouk olahan makanan ringan. Jurnal Sosial Humaniora . 9 (2). 144-158

Siyoto,Sodik,, (2015). Dasar Metodologi Penelitian, Sleman: Literasi Media Publishing

Susantio, Chandraningrum, (2019) Pengaruh Brand Image Oi-Dakk dengan penggunaanEndorser untuk promosi di Instagram terhadap Minat Beli Konsumen. Prologia. 3 (1). $238-24$ 